\title{
Concepts of underwater experimentation
}

\author{
J. A. Отт \\ I. Zoologisches Institut, Universität Wien; \\ Wien, Austria
}

KURZFASSUNG: Konzepte der Unterwasser-Experimentation. In den letzten zehn Jahren sind Unterwasseruntersuchungen zu einem nicht mehr wegzudenkenden und wichtigen Bestandteil marinbiologischer Forschungen geworden. Die technische Entwicklung dieser methodologisch definierten Disziplin führte vom Schwimm- und Gerätetauchen zu Tauchbooten, Unterwasserhäusern und ferngesteuerten Fahrzeugen. Die Anwendungsbereiche umfassen Beobachtung und Aufsammlung bis zur genauen Messung und Probennahme für ökologische Untersuchungen. Echte experimentelle Arbeit wird jedoch noch immer fast ausschließlich im Laboratorium durchgeführt. Daher ist Experimentation noch immer auf eine begrenzte Auswahl an "haltbaren" Organismen, eine begrenzte Zahl simulierbarer und kontrollierbarer Faktoren und insbesonders an einen begrenzten Komplexitätsgrad der Untersuchungsobjekte gebunden. Dies ist um so bedauerlicher, als sich in der Okologie immer deutlicher die Notwendigkeit von Systemanalysen abzeichnet. Der gegenwärtige Standard in Unterwasserbeobachtung und Datengewinnung und die Entwicklung von Multivariatentechniken macht es möglich, die „kontrollierten Bedingungen " im Laboratorium - die zu of eine gefährliche Vereinfachung sind durch die "gemessenen Bedingungen" in situ zu ersetzen. Die Dringlichkeit experimenteller Arbeit an ökologischen Systemen kann nicht genug betont werden in einer Zeit, in der wir versuchen müssen, mit den Einflüssen unserer Zivilisation auf die natürlichen Lebensräume fertigzuwerden, Voraussagen treffen und Modelle entwickeln zu können.

\section{INTRODUCTION}

The "International Helgoland Symposium 1972" sponsored by the Biologische Anstalt Helgoland is concerned with the topic "Man in the Sea", emphasizing the establishment of underwater observation and experimentation as an integral part of marine biology. With the increasing popularity of skin and SCUBA diving, underwater research has become a source of attraction for scientists and students towards the sea.

Like many biologists of my age, I have been deeply influenced by the popular books and films of HANS HASS and JACQUES CoUSTEAU. Even after I realized that marine biology is not all adventure, I still identify it with underwater research.

The scope of scientific diving, especially the exploration of the littoral benthos, together with brief historical remarks, has been reviewed by RrEDL (1967). I will consider here recent advances in technology only briefly and concentrate on underwater experimentation. 


\section{DEVELOPMENT OF UNDERWATER RESEARCH}

Despite the early efforts of Milne-Edwards (1845), who dived in Sicily in the first half of the 19th century to "pursue marine animals into their hidden retreats", and although ANTon Dorrn insisted on the need for in situ studies using diving apparatus already in 1880 , diving did not become popular among marine scientists for a long time. Divers were employed mainly for sampling purposes especially in habitats where the conventional gear produced little or no results. Classical papers by BERTHOLD (1882), Gislen (1929), Kitching (1941) and others demonstrated the usefulness of divers, while methods and scopes of investigation changed. It was not until advances in technology made diving easier and safer and until inquiry shifted towards complex structures and interrelations, that scientists rediscovered the need to enter the sea themselves.

\section{Advances in technology}

Modern underwater research started in 1943 when CoUSTEAU and GAGNAN completed development of the first Aqualung. The military potential of this apparatus directed considerable funds into the development of diving equipment. With accessories such as masks and fins on the market, skin diving and spear fishing became popular sports. Underwater housings for cameras were built and the first scientific underwater expeditions conducted. Courses in marine biology began to rely more and more on direct observation. SCUBA gear and compressors appeared in the inventory of all major stations, and many marine biologists became familiar with the use of this equipment. The sixties have brought yet another step in the development of technical aids for man in the sea. Again, most of the recent advances in technology have been made by military organisations and are designed primarily for military use. However, some are available for scientific purposes and in the wake of military development some are designed for scientific use.

To enable divers to work in greater depths new respiratory gas mixtures have been tested. The most common mixture uses helium as inert gas; tests have also been made with hydrogen and neon. These gases are commonly used in semiclosed- or closed-circuit rebreathing apparatus, such as Westinghouse's Abalone, General Electric's Mark, Dräger's F 66 III (Fig. 1), SMS I, SM III or Starck-Kanwisher's Electrolung. To reduce the decompression problem, which increases with the use of helium, saturation diving from underwater habitats has been extensively employed. Cousteau's Precontinent, first tested in 1962 off Marseilles, was soon followed by the US projects Sealab I and II, and Tektite I and II. The latter included extensive use of facilities by biologists. The small British underwater house Glaucus and the West German UWL-Helgoland have been constructed exclusively for the purposes of marine biology. Scores of underwater habitats have been built between 1962 and today in many different countries, including the Soviet Union's Kitjesch (1965), Ikthiandr 66 (1966), Sadko 1 (1966), Oktopus (1967), Ikhtiandr 67 (1967), Sadko 2 (1967), Chernomor 1 (1968), Sprut (1968), Ikhtiandr 68 (1968), Chernomor 2 (1969), Sadko 3 (1969), Cuba's Caribe I (1966), Poland's Medusa I (1967), and Medusa II (1968), 
Bulgaria's Hebros I (1967), and Hebros II (1968), The Netherland's Kockelbockel (1967), Australia's UWL-Adelaide (1967-1968), Romania's Romania LSI (1968), Italy's Robinsub I (1968), Robin II (1969), Atlantide (1969), the Federal Republic of Germany's BAH I (1968), BAH II (1969), and UWL-Helgoland (1969), the German Democratic Republic's Malter I (1968), and land-locked Czechoslovakia's Permon II

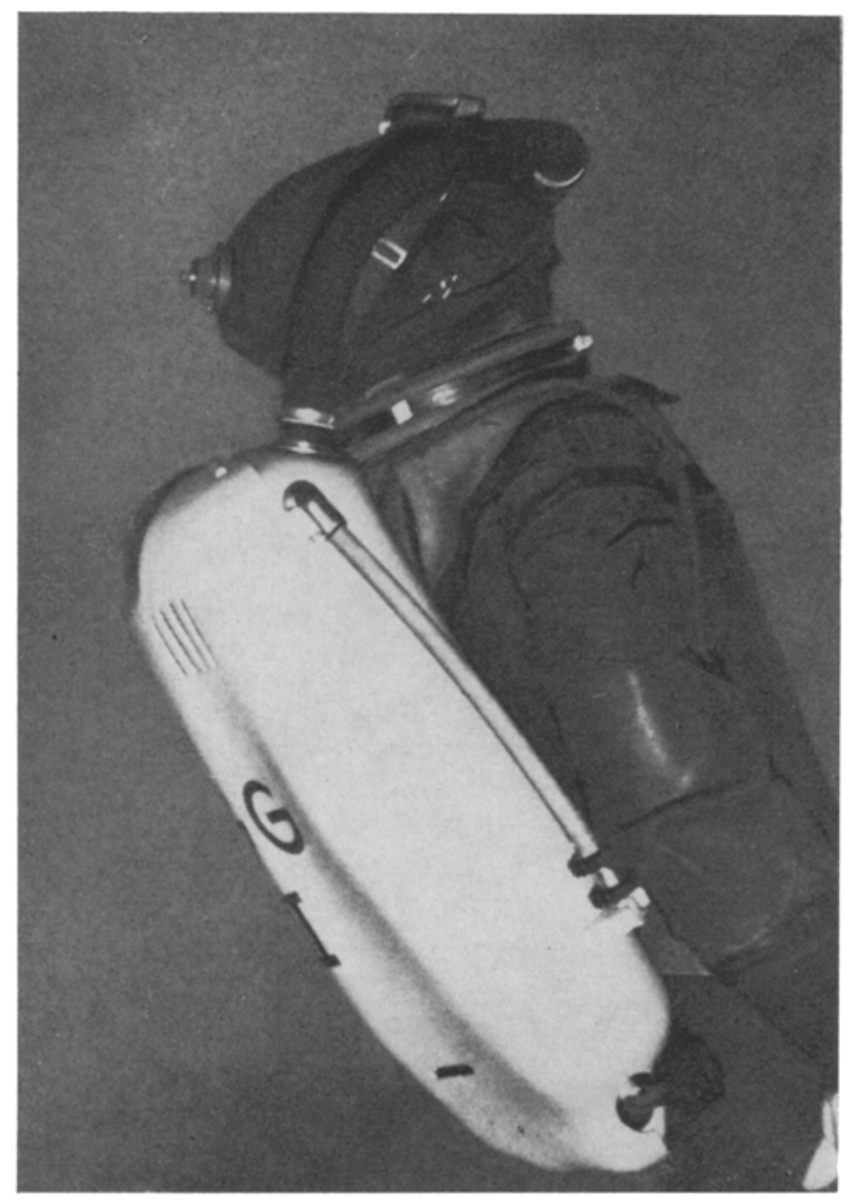

Fig. 1: Mixed gas rebreathing diving apparatus (semiclosed circuit) FGG III, manufactured by Dräger (Lübeck) for depth down to $200 \mathrm{~m}$. (After HAux 1969)

(1966), and Karnola (1968) (Fig. 2). It has become possible now, to rent underwater houses for three persons, at the reasonable price of 250 Dollars per day (Perry Hydrolab). The initial depth of operation, which was $10 \mathrm{~m}$ in Precontinent $\mathrm{I}$, has been extended to $183 \mathrm{~m}$ during the abortive mission of Sealab III.

Parallel to these developments, manned, deep-sea submersibles have been constructed which are manocuverable and equipped with cameras and manipulators 
Concepts of underwater experimentation

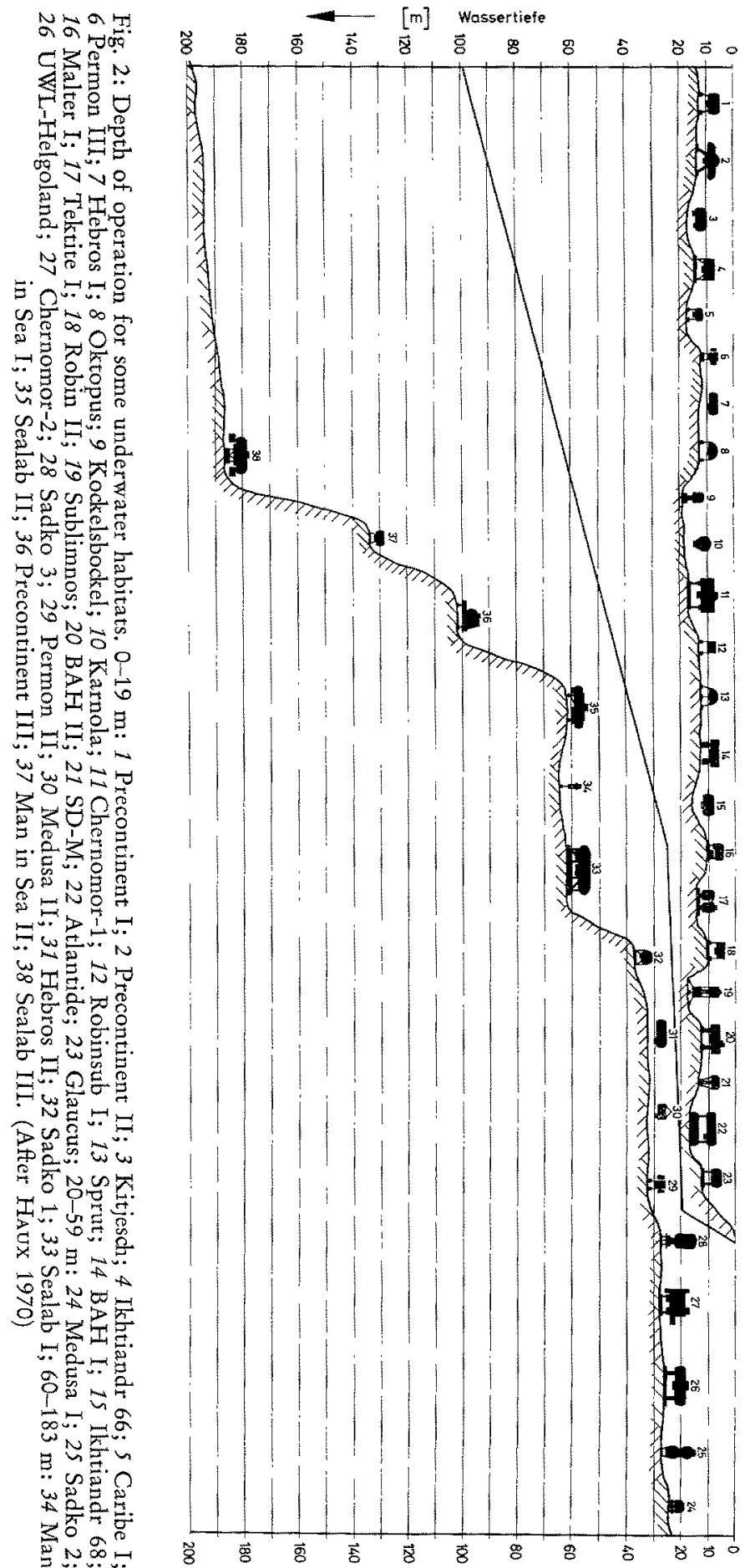


(Piccard 1966, Hull 1967, Rechnitzer 1967): the American Aluminaut, Deep Jeep, Star, Deepstar, Sea Cliff, Albacore, Barracuda, Dolphin, DSRV-1 and -2, Necton Beta, Nemo, Deep View, the famous Alvin from Woods Hole and the Perry PC-8, the diver lock-out submarines Deep Diver, Deep Quest and Beaver, the Canadian HYCO SOL 1, and the Japanese Yomiuri and Kuroshio I and II.

Unmanned underwater vehicles seem to have attracted less attention (REBrкofF 1967). Télénaute, Snoopy, Curv III and Sea Drone are examples of TV-equipped, unmanned vehicles which can be operated in constant depth or constant distance to the sea floor. Examples of sea-bed vehicles, which move on the bottom on caterpillar chains, are the Rum from Scripps Institution and a new model developed in Germany by Hagenuk. Another model is under construction in the Institut für Meeresbiologie in Vienna, Austria; it will be operational next summer (Fig. 3).

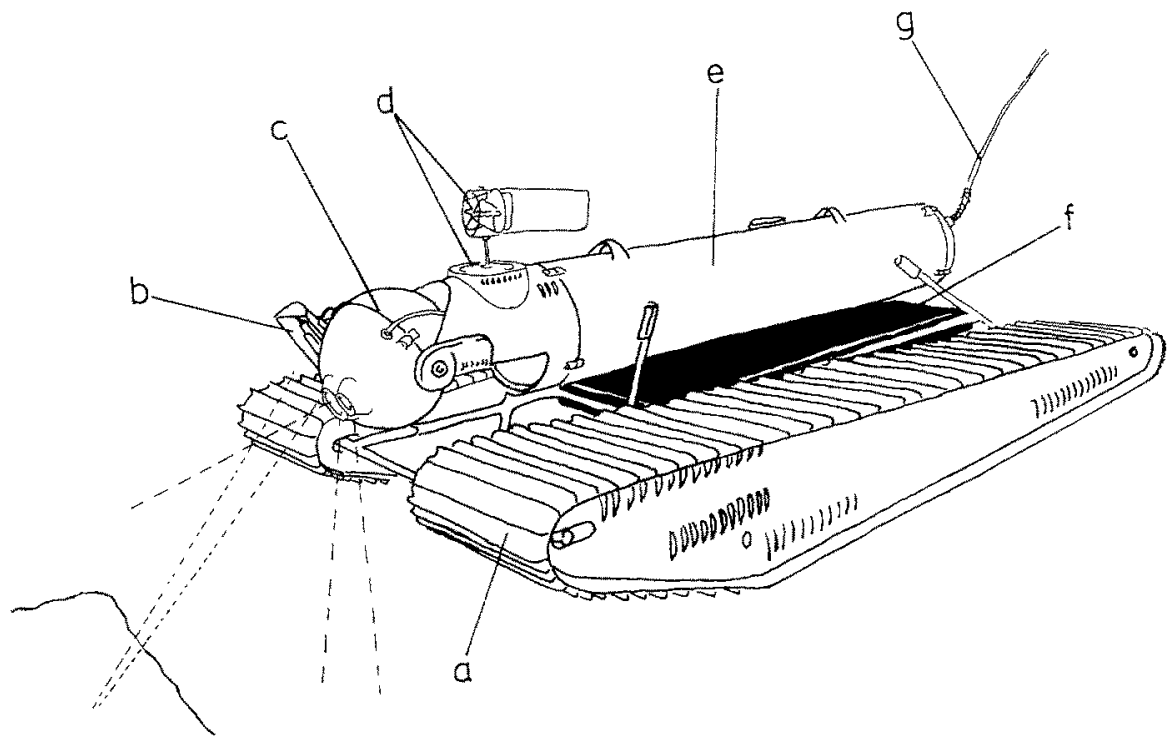

Fig. 3: Unmanned, remote-controlled sea-bed vehicle equipped with TV, movie camera, still camera and probes. $a$ caterpillar chains; $b$ spotlights and flash; $c$ camera housing; $d$ probes; $e$ flotation tank; $f$ weight; $g$ cable. (After RIEd 1963)

With regard to the techniques for sampling and measuring the parameters of interest, biologists have been active to adapt the methods available for use in the littoral. FAGER et al. (1966) list a series of useful aids for the underwater ecologist. Special sampling devices have been designed by WALKER (1967), BRETT (1964), BARNETT \& HARDY (1967). Automatic registration units for long-term recording of temperature, speed and direction of water movement, light, $\mathrm{pO}_{2}, \mathrm{pH}, \mathrm{Eh}$, pressure and salinity have been described by BERNARd (1967), Forstner \& RÜTzLer (1969, 1970, Fig. 4), Machan \& OTt (1972), Riedl \& Machan (1972), benefiting from the development of underwater electric connectors, underwater mating cables, polarographic electrodes, semiconductor techniques, etc. 


\section{Advances in application}

Applications in marine biology also changed with time. Discovery of new organisms and of new biomes was the first step. Skin and SCUBA diving opened up new worlds to the biologists, such as the rocky subtidal with its kelp forests and sea caves,

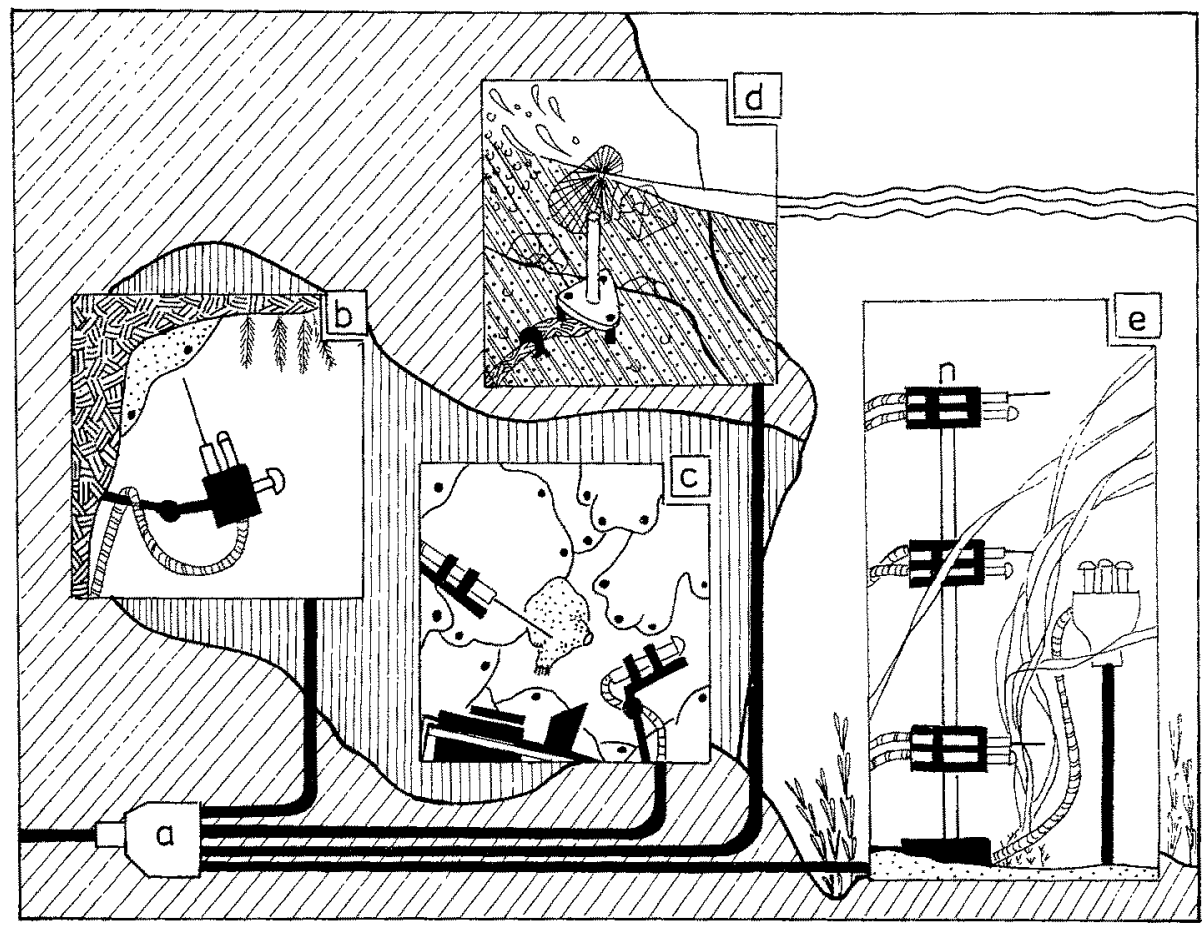

Fig. 4: Automatic recording of speed of water movement, $\mathrm{pO}_{2}$, light intensity and spectral composition and strain in the rocky subtidal and in a stand of sea grass. (After ForsTNER \& RüTZLER 1970)

or the deeper areas of coral reefs. Similary, deep-diving submersibles lead us now to the edge of the continental shelf, into submarine canyons and beyond into the true deep sea.

It was soon realized that samples taken by divers yielded better and more precise information on the distribution and abundance of organisms than had been produced previously by use of dredges and grabs employed from research vessels. However, the basic scientific problems and interests still concerned mainly the number of species and individuals in a given area.

The new underwater capability of man further provided new insight into the enormous complexity of organismic assemblages in biotopes such as the primary and secondary hard bottoms, caves and reefs. Recently, mobile bottoms too have attracted the attention of diving scientists (RHOADs \& Young 1971, Young \& RHoAds 1971, 
Rice \& Chapman 1971, Chapman \& Rice 1971). Similar advances have been made in our knowledge on behaviour and other functional interrelations between organisms.

In situ experimentation, however, is still a virgin field. Compared to the level attained in terrestrial ecology or ethology, the marine ecologist conducting experiments in the sea, is still several decades behind. Therefore underwater experiments are urgently needed and seem to be feasible technologically.

\section{UNDERWATER EXPERIMENTATION - DEFINITIONS}

\section{Brief consideration of the term "experimental"}

In his stimulating paper presented at the "First European Symposium on Marine Biology", BARNES (1967, p. 11) provided a rather rigid definition of an experimental procedure: "The activity in which a given system is observed when it is subject to a set of conditions whose values ... are selected and, ideally controlled by the observer". But he adds that "in the case of a fully natural ecosystem rarely can an experiment, as so defined be carried out". Hardly any ecologically meaningful experiment can meet this definition, neither in the field nor in the laboratory. At the present state of our knowledge, the scientist will have to be content with defining an experimental procedure as the purposeful alteration of one or more parameters of a system, while controlling or, as is the case in most field experiments, measuring and recording as many other parameters as possible and establishing a correlation between the change induced and the effect produced on the variables of the system. "Purposeful" designates the attitude of the experimenter, which provides the basis for distinguishing qualitatively a change induced in an experiment from the unavoidable change caused by every observation or measurement (BARNEs 1967). A bell-jar "experiment", for example, becomes an experiment only if antibiotics are added (SMrTH et 21. 1972); this is true even if one has to make assumptions, i.e. regarding the drop in oxygen tension during the measurement.

\section{What do we understand by underwater experimentation?}

Underwater experimentation is a special case of general field experimentation and deserves special interest only because the experimenter operates in an environment to which he is not physiologically adapted. Underwater experimentation should, therefore, be defined on methodological grounds rather than physiographically. It is not the position of the experimental site but the specific methods that enable the experimenter, or a mechanical substitute, to perform this experiment. This equipment may be a simple skin diving outfit, SCUBA gear, submersibles, underwater habitats or remote-controlled vehicles, etc. The definition provided excludes most work performed in the intertidal; it also excludes experiments conducted from above the surface such as the lowering of experimental flasks for studying productivity or the immersion of plates in fouling experiments. Work of this kind, therefore, is not referred to in the following section. 


\section{Examples of underwater experimentation}

Although the above definitions do not draw very narrow limits around the term underwater experimentation, I was surprised, when reviewing the pertinent literature, how carefully some investigators avoided experimentation which could have contradicted or supported their sometimes very complicated hypotheses. General remarks on

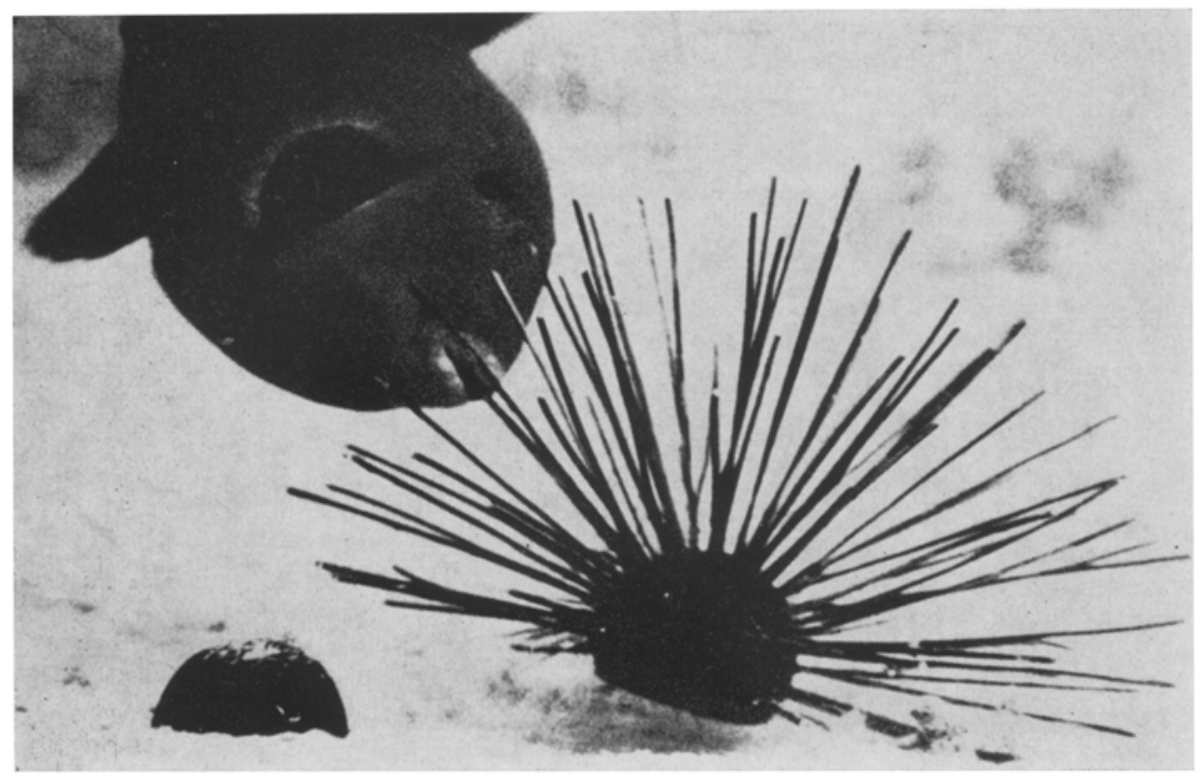

Fig. 5: Trigger fish attacking a dummy sea urchin with spines while ignoring a spineless choice. (After FRICKE 1971)

the kinds of underwater experiments which can be performed with comperatively simple means have been provided by BARNES (1967) and KINNE (discussion remark to RiEdL 1967).

Simple experiments, using the disturbance created by the diver, have been performed by KüHLMANN \& KARST (1967) and FRICKE (1970) with regard to the schooling behaviour of fishes. Similar simple experiments characterize a whole series of papers, also devoted to fish behaviour. Defence of the nest was observed by placing natural objects in it (CLARK 1970), homing was investigated by tagging and release at various distances (Aber 1962, Clark 1970, Stephens et al. 1970), dummies were used to obtain insight into organismic interactions (ABEL 1962, 1971, FrICKE 1966a, b, 1971, Fig. 5).

In situ experiments designed similar to laboratory experiments have been carried out using the sea as a suitable incubation place for algae (RUSSEL 1967, LüNING 1969), hermatypic corals (Goreau \& Goreau 1959, 1963), (Fig. 6) or bivalves (Levinton 1971). Also the underwater cages used by WATERMAN \& ForEWARD (1972) in sensephysiology studies, the experiments on the orientation of lobsters during the UWL-H 
programme (KINNE 1970a) and the Trichterkreisel (JATZKE 1970) should be mentioned in this context.

Removal of sea urchins has been used to study the biology and ecology of algal growth (Jones \& KanN 1967, PAINe \& VAdas 1969). PAtTon (1967) removed commensals from a coral and observed recolonisation. Behaviour-ecological studies, e.g. on the importance of cleaning symbioses, have been conducted by Limbaugh (1961) and Youngbiuth (1968) who removed all cleaning organisms from a reef area and observed the resulting effects on the hosts.

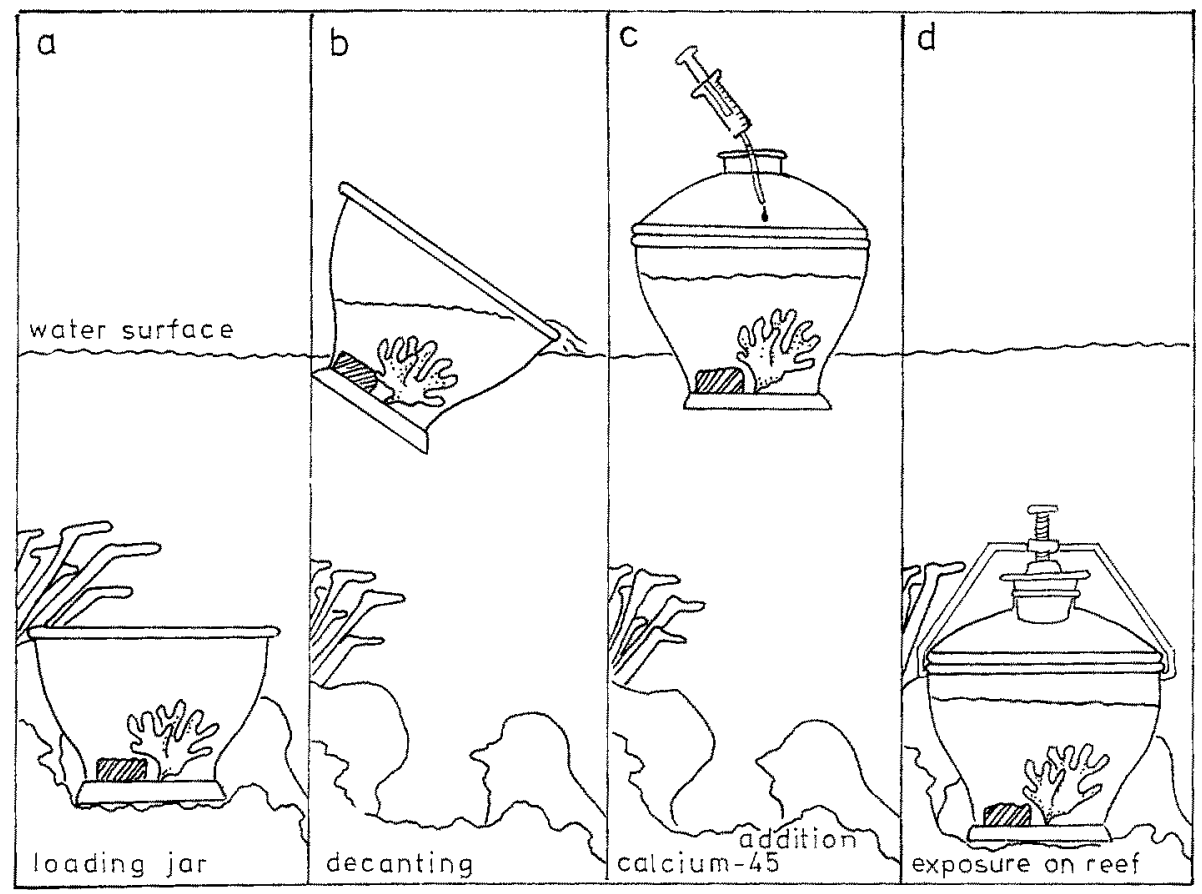

Fig. 6: Incubating a piece of coral in a jar under field conditions. (After Gorkau \& Goreau 1959)

Transplantation experiments have also been performed without great technological effort. NorTH (1961) and Neushul \& Haxo (1963) transplanted Macrocystis pyrifera, LüNING (1971) Laminaria byperborea plants into different light regimes while monitoring light intensity with underwater light meters, and OTT (1969) transplanted Cystoseira spp. plants into zones of different water movement to test the stability of meiofauna zonations associated with these algae. Svoboda (in preparation) and Velimirov (1973) investigated the orientation of fan-shaped hydroids and gorgonians by turning and transplanting colonies (Fig. 7).

Natural and artificial substrates have been placed in defined locations and under defined conditions in studies on seaweeds (HAage \& JANSSON 1970), Ascidia (DYBERN 1969) and boring organisms (NEUMANN 1966). 


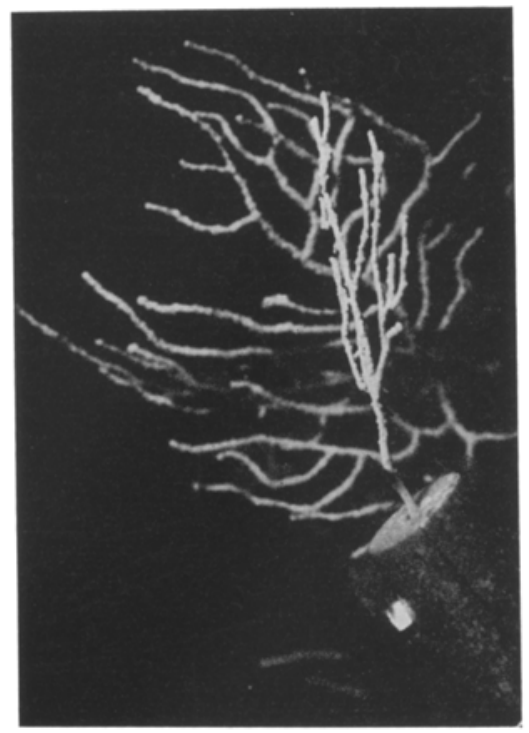

Fig. 7: Sea fan (Eunicella cavolinii) rotated $90^{\circ}$ from its previous position. (After Velrmirov 1973)

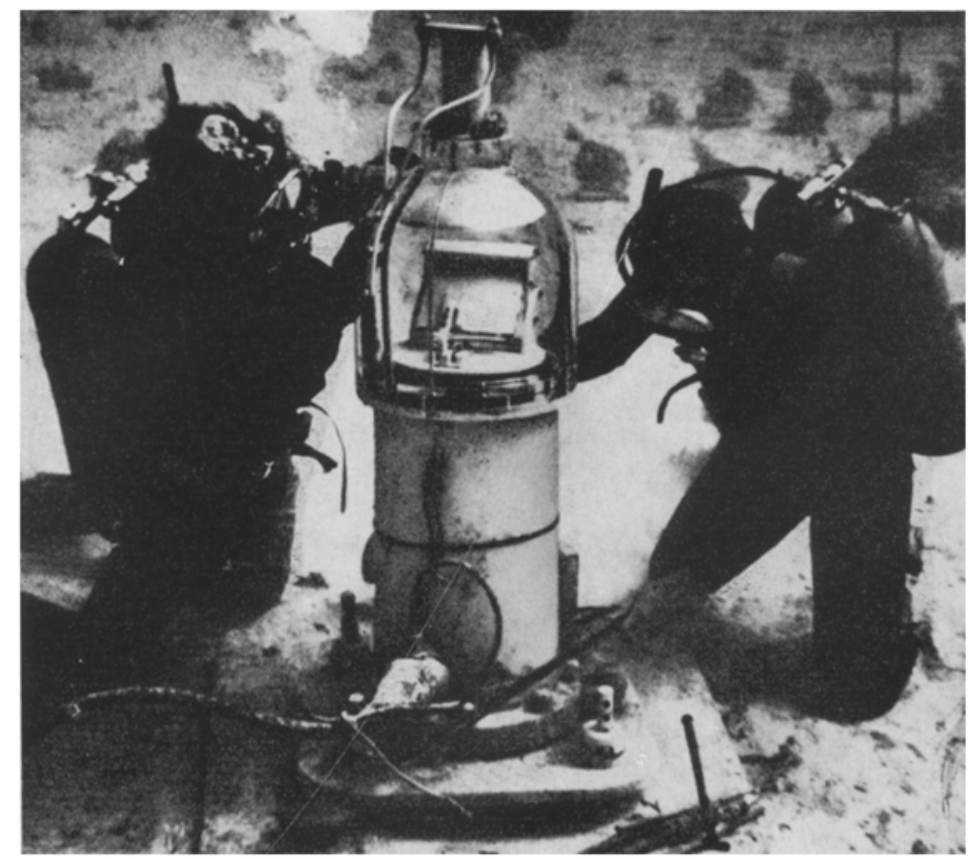

Fig. 8: TV camera with remote-controlled pan and tilt for recording activity of sharks. (After Myrberg et al. 1969) 
The author has attempted to influence physical parameters in situ by reducing water movement around a plant of Cystoseira adriatica with the aid of a nylon mesh cage to trigger short-term migration of the nematode fauna in the dense epigrowth. More complex biological interactions have been studied by SMITH et al. (1972) who used antibiotics to intercept bacterial respiration in the sediment during bell-jar measurements.

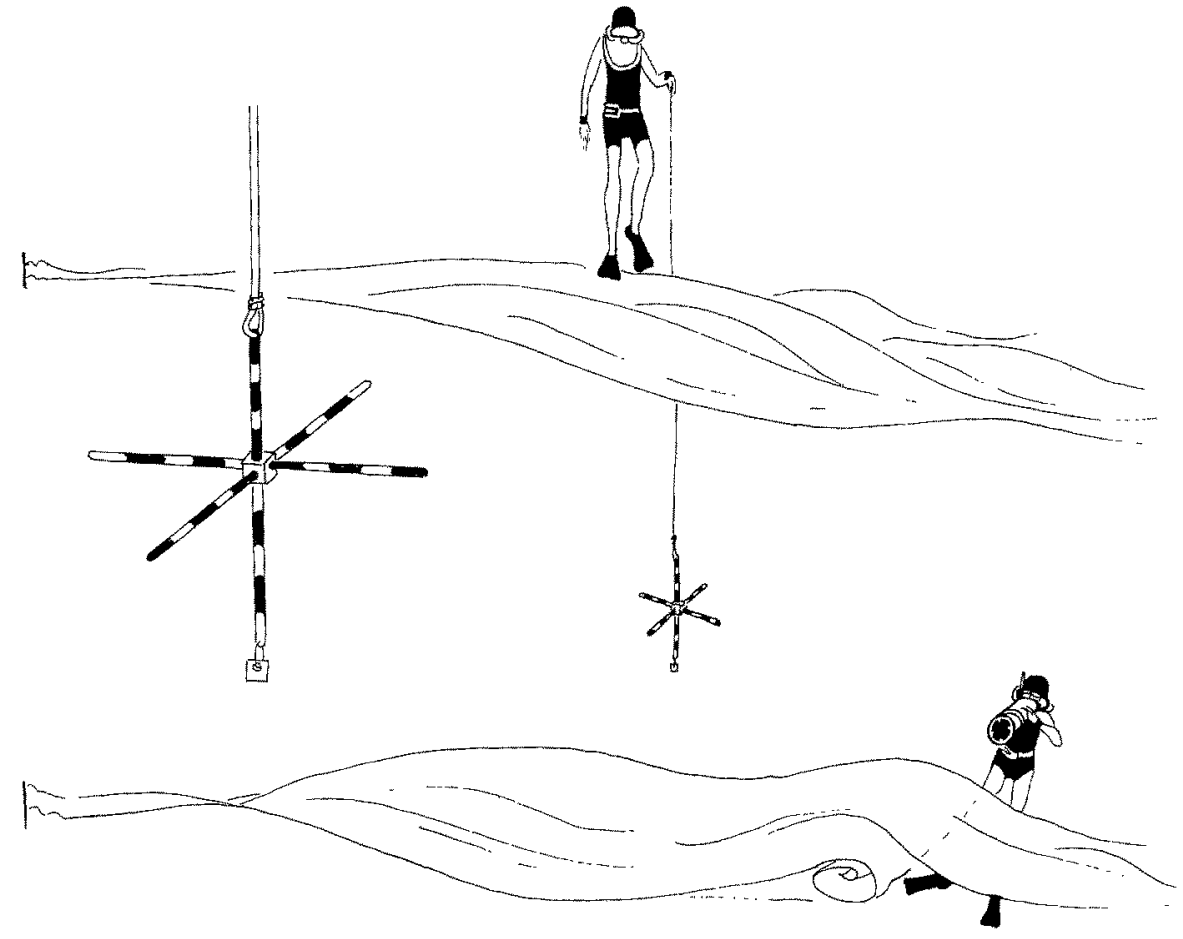

Fig. 9: Underwater experiments with divers and dyes used in micro-oceanography. (After Woons 1971)

More complicated apparatus has been used to set visual (Neshyba 1967) and acoustic (MYrBerg et al. 1969) stimuli and record the effects (Fig. 8).

In oceanography, underwater experimentation has created a new field of enquiry: micro oceanography. The development in this field has been summarized by Woons (1971) (Fig. 9).

\section{LABORATORY EXPERIMENTATION VERSUS UNDERWATER EXPERIMENTATION}

There are fields in marine biology where underwater experimentation will remain impractical, or of no or so little advantage that it does not justify the additional expense necessary. Examples are biochemistry and much of the pure physiological work. Ethology, ecophysiology and ecology, enjoy maximum advantage of the new 
possibilities. One field in ecology, namely systems studies, depends almost entirely on in situ experiments.

\section{Limits inherent in the research objects}

Experimental organisms must often be selected disregarding the primary interest of the investigator or the suitability for solving the problem under investigation. More often, the experimenter has to be content with a second choice, which meets the basic requirements for a laboratory experiment: sufficient tolerance to survive and perform under the conditions offered. If in addition, experiments require the organism to feed, grow, complete life cycles, or reproduce the number of objects available becomes very limited indeed. Thus there exist only few experimental data on important groups such as benthonic brown algae (Laminariales), calcareous red algae, eel grasses, sponges, thecaphore hydroids, madreporarians, gorgonians, sea pens, alcyonarians, bryozoans, opistobranchs, hemichordates, pelmatozoans. From other groups, only a few species have been cultivated successfully. KINNE (1970b) states that only $2 \%$ of all known marine organisms can presently be reared throughout their whole life cycle under controlled conditions, despite the recent effort in designing new apparatus for cultivation (Greve 1968, Svoboda 1970, Zillioux \& Lackie 1970, Zillioux 1969, Lickey et al. 1970).

The main problem seems to be the provision of or substitution for biological parameters such as food and the complex relationships between two or more co-existing organisms. Physical parameters are more readily simulated, except, for example, high pressure, or complicated patterns of water movement in the case of organisms from the rocky littoral (SvoBod 1970).

Even when one succeeds to bring an organism into the laboratory without irreversible damage and gets it to "perform" in an experiment, doubt remains whether this performance resembles its behaviour in nature. STEINBöck (1942), experimenting with the freshwater planarian Planarina alpina presented a strong case against the ecological relevance of some laboratory results. HEMmINGs (1971) states that all experiments on swimming speed and endurance of fishes are suspect owing to the problem of handling and maintaining during captivity.

In summary then, there is still only a very limited number of experimental organisms available for laboratory studies and their responses have to be compared critically with those exhibited under natural conditions. Since we are, in most cases, interested in general principles of marine biology rather than in the behaviour of some rare species, such selection should not worry us too much; however, the selection is not random and we are in danger of deriving our conclusions from studies on the most euryoecious and unspecialized organisms.

\section{Limits of "controlled conditions"}

Provided an organism survives and seems to be able to perform in the laboratory, it becomes subject to experiments under "controlled conditions". This means, in many 
cases, that some basic parameters are known, such as the size of the experimental vessel, temperature, salinity, sometimes - if it deemed necessary - illumination or partial pressures of dissolved gases. Rarely can the medium in which an experimental organism is kept and expected to perform be defined better than an aqueous solution of some major ions in standard proportions, whose concentrations are "controlled" in terms of density or chlorinity. Artificial sea water may lack necessary trace elements and dissolved organic substances (e.g. HavenscHILD 1970) which might be essential; natural sea water mostly may come from polluted locations, flow through pipes of unsuitable material, spend undefined times rotting in containers and undergo questionable filter techniques; it tends to be loaded with nitrogenous compounds and carbonic acid at the time it is used in an experiment.

In underwater experiments, one can at least define the sea water used as being the same in which the organism lives. The parameters "controlled" in the laboratory, can be monitored. Detailed evaluation of the results, requires multivariate analyses. But this is no big problem with the increasing number of computers available.

\section{Limits of complexity}

Problems get worse if one wants to deal with systems instead of single organisms. In its simplest form a system consists of two interacting parts. From this interaction special laws governing the behaviour of the system are derived which cannot be deduced from the behaviour of the isolated component. Such simple systems would be predator-prey relationships or a symbiosis. Systems are always subsystems of others in an hierarchical order up to the great system of our biosphere where we leave the field of biology.

Few of these systems have been successfully experimented upon in the laboratory. Most of them have been of the simple kind involving only two organisms, as in symbiosis studies. But even such basic systems have been more effectively studied in the field if accessible such as the competition and predator-prey studies by CONNEL.L (1961, 1970). A notable exception are the sand column studies conducted in the Aberdeen Laboratory by MCINTYRE et al. (1970) and similar experiments by RIEDL, MACHAN \& HALL (personal communication) where the sand-meiofauna-microbe-system has been investigated. But even in this case the experimenters have to admit that the system might be simplified and thus has all the disadvantages common to microcosm studies in systems analysis.

The difficulties of bringing systems undisturbed into the laboratory or re-assembling them there constitute a great disadvantage, especially in ecology which is by definition a study of systems (BARnes 1967). The great lead of terrestrial ecology in system studies has been attained by extensive use of in situ experimentation, and the few system analyses performed in marine ecology have not yet reached the subtidal (Odum \& Odum 1955, Teal 1962). Unless similar techniques can be used underwater we will remain in a descriptive stage of field observation and experimental biology. 


\section{MANNED VERSUS UNMANNED UNDERWATER STUDIES}

There are several reasons why some marine ecologists still hesitate to turn to in situ studies, even in view of the inadequacies of laboratory experimentation listed above. Diving has a reputation of being dangerous and requires sportsmanship and training. This results in a selection of underwater scientists on the basis of physical fitness rather than on a pure intellectual basis. Furthermore, the working capacity of an experimenter underwater is considerably less than that of the same person on land. Underwater remote-controlled devices are of help here and are strongly advocated by scientists who have contributed much to marine biology.

\section{Limitations of the underwater observer}

"As soon as the diver leaves the surface he begins to get cold and fuddled and stupid" - these words introduce a book entitled "Underwater science" by Woops \& LyTHGoE (1971). Even in shallow water, concentration suffers from discomfort, difficulties of controlling body movements, handling of bulky equipment, communication,

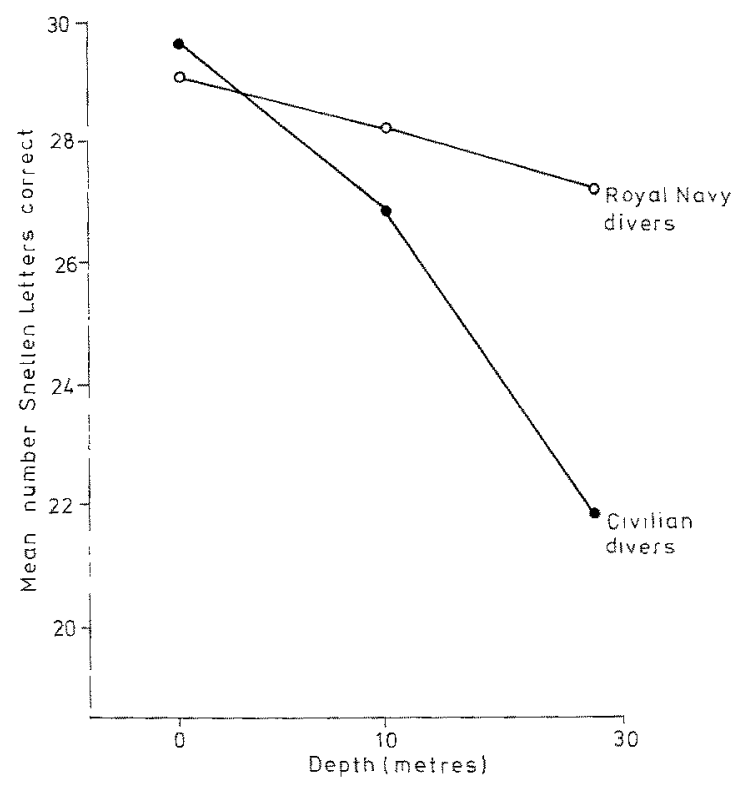

Fig. 10: Visual acuity test for divers breathing air (closed circles) and a 40:60 oxy-nitrogen mixture (open circles). (After BADDELEY 1971)

and data recording. WELTMAN et al. (1967) found "perceptual narrowing", typical for stress situations (WATCHEI.L 1967), in divers tested both in experimental tanks and in the field. The intensity of this phenomenon seems to be correlated with anxiety and 
should, therefore, be expected to play a minor role in experienced divers. However, only a small number of diving scientists can be classified as such.

Apart from this, there are the well-known and well-documented impairments of visual performance (BARNARd 1961). Even visual acuity, which could be expected to improve by the magnification effect - as has been shown in tank experiments (FAUST \& Beckmann 1966, Kent \& Weissmann 1966, Christiansson 1968) - deteriorates markedly when tested in the sea (Fig. 10). The differences observed cannot be explained by absorption and scattering (BADDELEy 1968). Depths exceeding $30 \mathrm{~m}$ may cause

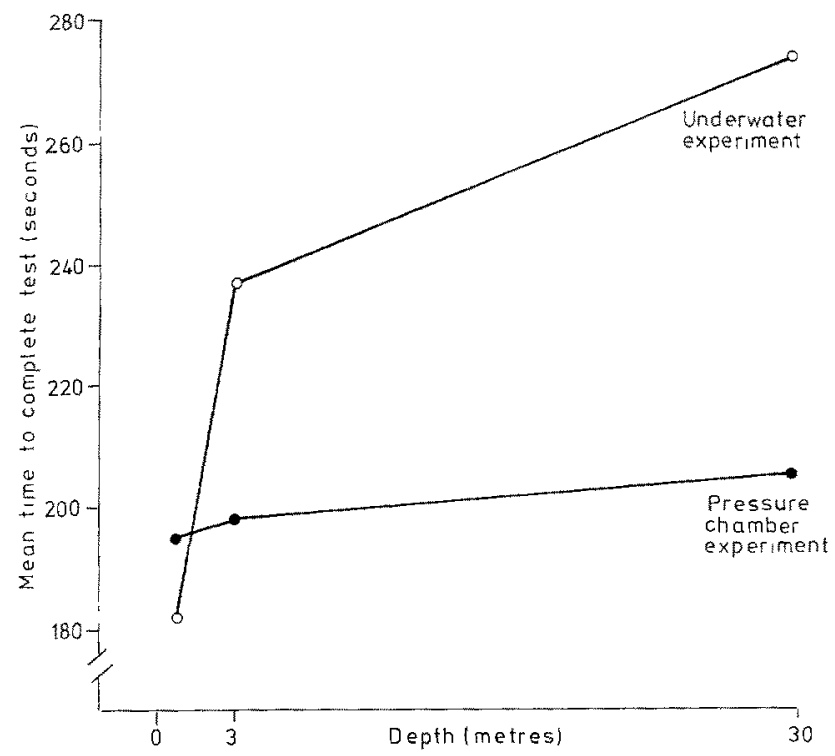

Fig. 11: Test of manual dexterity under dry pressure chamber and open-sea conditions. (After BADDELEY 1971)

inert-gas narcosis. The associated drop in mental and manual performance - well documented in dry pressure chamber tests (BADDELEY et al. 1968, BENNETT et al. 1967, Poulton et al. 1964) - is strongly aggravated in open-sea diving experiments (BADDELEY 1966), presumably because of the associated stress (Fig. 11). This is another example which demonstrates the advantage of underwater experiments over the "dry run" when studying complex interactions. Saturation diving, possible from underwater habitats, can reduce some of the difficulties, especially when using oxy-helium mixtures (Bowen et al. 1966, Hamilton et al. 1966, Krasberg 1967), and the minimum depth for narcosis seems to lie deeper (BenNetT 1966, Adolfson 1967, Baddeley \& FlEMMING 1967). Maybe neon will be the answer (BennetT 1966). Pure oxygen seems to have no effect on performance down to the depth where it suddenly causes unconsiousness, usually near $12 \mathrm{~m}$ (FranKenHAUSER et al. 1960).

None of these restrictions apply to non-manned mechanical devices. In contrast to human physiology, they can be designed for underwater performance in any depth 
desired. Their acuity and reliability can be defined quantitatively. Admittedly, they can break, but the engineer in charge can usually tell you what was wrong. In the case of optical documentation, the now available corrected lens systems for underwater use are far superior to the human eye, and information is readily stored for evaluation under comfortable conditions by film and TV tape. Time lapse and slow motion open up a new dimension in observations conducted over longer periods.

\section{Physiological depth limits}

Whereas the foregoing section was mainly concerned with the limits of mental and manual acuity of the experimenter, the two following sections deal with his physiological limits.

There is a depth below which the effect of inert gas narcosis can no longer be treated as an annoying impairment to the experimenter's performance, but where it becomes dangerous. These depths vary considerably with the type of breathing apparatus and gas mixture used. For common compressed-air units, safety limits lie between 70 and $90 \mathrm{~m}$. The danger involved is that the depths where the different signs of "Tiefenrausch" - from nausea to euphoria - appear, depend strongly on the physical and, even more, on the psychological state of the diver. The stress of carrying out an experiment that involves careful planning, much time and money, and requires much skill in setting it up, might add to the normal anxiety of an inexperienced diver. Oxyhelium mixtures can extend these depths considerably, and there are enough submersibles which are virtually unlimited in their operational depth range.

\section{The limits of time}

Man underwater faces a series of time limits. Probably the most serious is the diver's oxygen supply or the oxygen and energy supplies of submersibles. Thus there is only a certain time span a vallable for completing descent, work and ascent.

One of the first things divers have to learn about is the caisson sickness or the "bends". To avoid caisson sickness, decompression time limits must be adhered to. Since the duration of the stops required depends on depth attained and time spent there, they seriously reduce the actual working time from $20 \mathrm{~m}$ downwards. Saturation diving from underwater habitats requires decompression only once, thus making additional time available for observations and experiments.

Even in shallow water, where the supply of breathing gas may easily exceed the amount needed and where no decompression requirements build up, the diver's activity is limited to comparably brief periods. In most cases heat loss is the biggest problem; this can be reduced for a limited time only. Furthermore, fatigue builds up much faster if one has to pay attention to things like breathing and controlling body movements, which operate subcortically on land.

It will be necessary, therefore, to relieve the diving scientist from as many complex operations underwater as possible. The experimental apparatus must be designed 
accordingly. Deposition of experimental devices in shallow waters can be done most effectively by SCUBA divers. In deeper locations, submersibles and unmanned remotecontrolled vehicles should be used (Fig. 12). Subsequent operations and all recording should preferably be performed either from land or aboard ship.

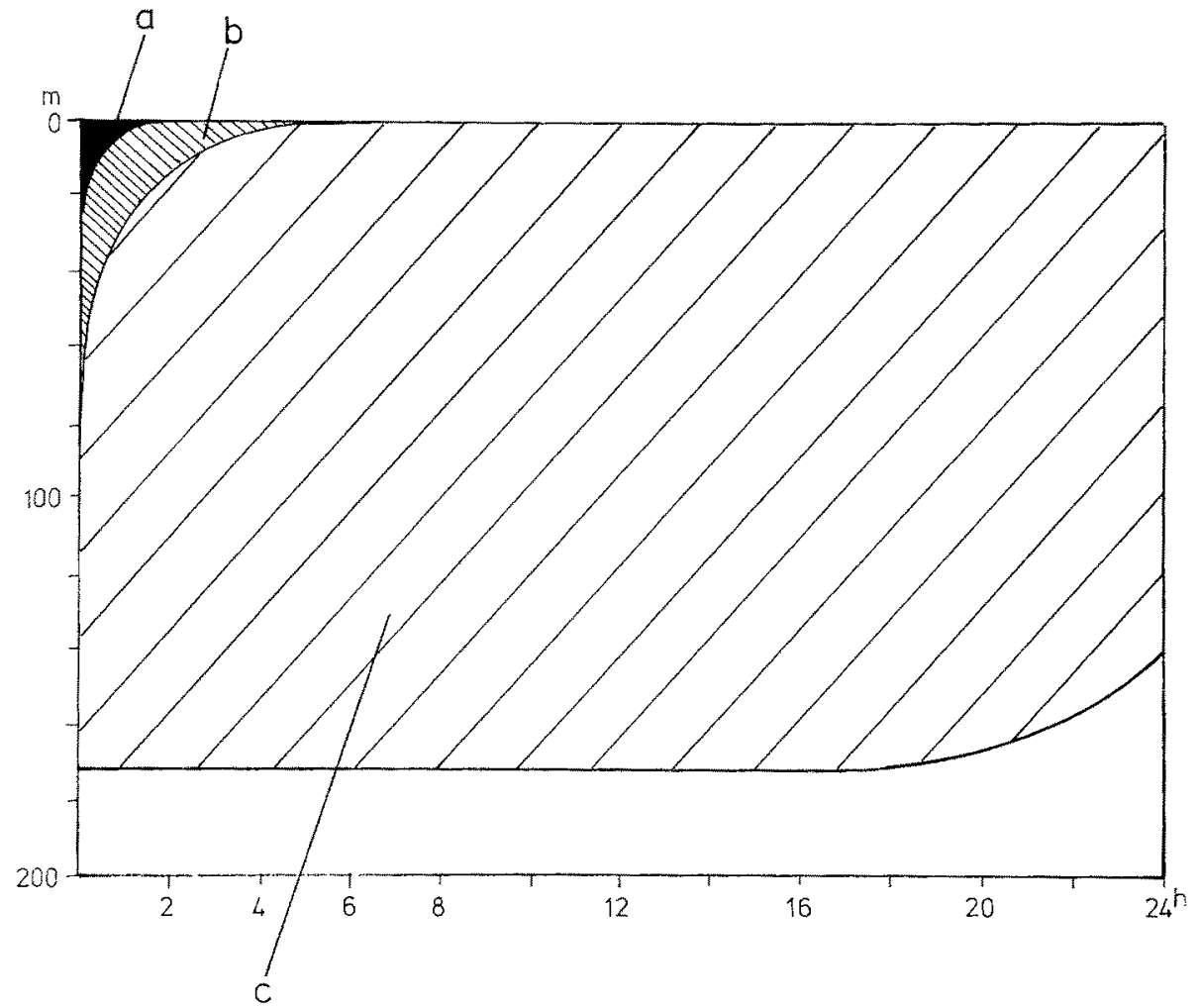

Fig. 12: Comparison of the time-depth fields of observation and maximum operation in a diver breathing air and the unmanned sea-bed vehicle under contruction in the Institute for Marine Biology in Vienna. $a$ field of useful observation by a diver; $b$ maximum field of operation in a diver; $c$ field of observation and operation in the remote controlled vehicle

\section{PROSPECTS IN UNDERWATER EXPERIMENTATION}

We have mentioned two fields already taking advantage of the new technical possibilities for conducting in situ studies: ethology and ecology. These two disciplines, and the area between them, behavioural ecology, will continue to benefit greatly from underwater research. Sense physiology, especially with regard to ecophysiological studies of hearing and seeing under water is next. Employing the new methods, scientists can now choose their abjects among the variety of organisms which have not yet been cultivated successfully under laboratory conditions, as well as conduct longterm experiments and experiments on systems under natural conditions. 


\section{From controlled to measured conditions}

Instead of employing constant temperature baths or calibrated illumination sources, the underwater experimenter has to measure and record as many parameters as possible which appear to be relevant to the problems studied.

\section{Need for autonomous registration}

To compensate for the laboratory conditions, under which the values of all relevant parameters are assumed to be known at any instant, recording in the field must not only include as many parameters as possible, but in addition must be simultaneous and continuous. This requires automatisation.

Most physical parameters can be recorded without technological sophistication and with fair accuracy. Thermistor probes record temperature and water movement; the Clark-type $\mathrm{pO}_{2}$ electrode records oxygen levels; conductivity recorders trace salinity variations; and measurement of spectral composition and energy of light, $\mathrm{pH}$ or redox potential present no difficulties. Nutrient levels or organic matter contents are more difficult to monitor and require frequent sampling. Experiments should be controlled by TV cameras or time-lapse motion-picture cameras if optical variations are to be recorded.

As Barnes (1967) pointed out, the easiest changes that can be made in a natural system are of a subtractive kind. Shading and filtering of light could reveal principles of the distribution patterns of algae and sedentary animals, reduction and change of mode of water movement could influence growth forms and the pattern of distribution in filter-feeding organisms. Removal of browsers or predators has been shown to provide insight into distribution patterns and population dynamics of other organisms (Connell 1961, PAINe 1966, Jones \& KaIN 1967). Additive changes are more difficult. Examples are the influence of constant light on the activity patterns of animals, especially sedentary organisms; the introduction of radio-active tracers in studies on metabolic performance (LUNNNG 1971); the use of antibiotics in assessing microbial activity and of substances to intercept respiration or photosynthesis. Also the controlled introduction of a new species would belong here.

A good possibility to bring about changes is to use natural gradients in transplantation experiments, especially with sedentary organisms (as has been done successfully in the examples cited); to modify speed, direction and pattern of water movement and record the effects on orientation of colonial fan-shaped coelenterates and on distribution and short-term migration of meiofauna.

For bigger vagile animals, underwater cages can be used and equipped with experimental devices or recording units. Behavioural studies can also use baits or dummies in connection with optical recordings.

\section{Need for multivariate techniques}

The natural variation of parameters during the time of an experiment, together with changes induced by the experimenter produces a mass of background data from 
which it is difficult to determine the effectiveness of a single factor. Multivariate techniques are required here, such as principal-component analysis or factor analysis. These techniques are time consuming even if only a few factors vary. Fortunately, electronic calculators and computers are now available to most biologists. To facilitate use of these aids, data should be prepared for digital processing. The most difficult task is to find appropriate methods for analysis.

\section{From single organisms to systems}

\section{Need for data on systems behaviour}

The methods of inducing the changes mentioned apply not only to single organisms but also to systems. A factor does not act on a single organism, nor can the change in a variable be without effect on the properties of the system of which the variable is a part. The pattern of water movement, the intensity and spectral composition of light, or the presence or absence of a browser or predator affects community boundaries, community metabolism, diversity, etc. (PAINE 1966).

We do not know much about successions in the marine environment except for some specialized cases such as the coralligene (LABOREL 1961). Experimental destabilizing of steady-state systems to trigger successions could give us insights into the history and future of marine biomes. This could be done by changing climatic and biotic parameters in enclosed, defined subsystems, in order to overcome the strong interdependences and exchanges which exist between marine biomes and which limit manipulation of research objects in contrast to, for example, agriculture. Sea caves could provide a model biotope for the rocky littoral; one could, for example, close one entrance of a submarine tunnel and thus drastically change the extent and mode of water movement.

The erection of underwater gardens, as proposed by KINNE (discussion remark to RIEDL 1967), and mariculture projects lead towards applied aspects of experimental marine ecology.

\section{Need for predictive models}

These data on systems behaviour should enable us to construct predictive models for assessing the potential fate of marine environments. Civilisation produces experiments on marine biota on a grand scale. Hot effluents from nuclear power plants heat up estuaries and bays, industries discharge wastes containing toxic compounds and heavy metals which poison the fish and shellfish we eat and change system variables like reproduction rates (GRAY \& VentrLla 1971); domestic sewage and excess fertilizers lead to eutrophication. Since it seems unrealistic to assume that the increase of energy flow through our societies, which is the basic cause of our pollution problems (ODum 1971), could be reduced, man has to learn to minimize detrimental effects and even to reverse them to his benefit.

The marine ecologist must learn to predict, with a fair amount of accuracy, the successions which follow a certain change in the environment, and to estimate the new 
level of equilibrium. The resulting recommendations for the protection of life in the sea must be understandable and acceptable for all members of society. At present, more questions are asked about pollution than there are answers available. Therefore we must know more about the structures and functions of living systems in the sea, and in situ experimental studies are, at present, the most important and the most promising means to provide such knowledge.

\section{SUMMARY}

1. Recent advances in underwater research are reviewed and critically discussed. New technologies include deep-sea diving apparatus, saturation diving from underwater habitats, submersibles and remote-controlled vehicles. The fields of application include increasingly ecology and animal behaviour.

2. The term "underwater experimentation" is defined and examples provided to illustrate pertinent research.

3. Underwater experimentation is compared to laboratory experimentation. The latter is restricted to a limited set of suitable organisms, which are subjected to "controlled" but frequently quite "artificial" conditions. Furthermore, only systems of a very low degree of complexity can be studied in the laboratory. Underwater experimentation is limited by the restricted performance of man under in situ conditions. Automatisation of experimental units and use of remote-controlled vehicles are proposed to enhance man's underwater capacity.

4. The need for the design of underwater experiments, especially for system analysis, is emphasized. There is an increasing demand for predictive models to anticipate the potential impacts of civilisation on the marine environment.

\section{LITERATURE CITED}

ABEL, E. F, 1962. Freiwasserbeobachtungen an Fischen im Golf von Neapel als Beitrag zur Kenntnis ihrer Okologie und ihres Verhaltens. Int. Revue ges. Hydrobiol. 47, 219-290.

- 1971. Zur Ethologie von Putzsymbiosen einheimischer Süßwasserfische im natürlichen Biotop. Oecologia 6, 133-151.

Adolfson, J., 1967. Human performance and behaviour in hyperbaric environments. Almquist \& Wiksell, Stockholm.

BADDELEY, A. D., 1966. Influence of depth on the manual dexterity of free divers: a comparison between open sea and pressure chamber testing. J. appl. Psychol. 50, 81-85.

- 1968. Visual acuity underwater: a review. Underw. Ass. Rep. 3, 45-50.

- 1971. Diver performance. In: Underwater science. Ed. by J. D. Woods \& J. N. LYThgoe. Oxford Univ. Press, London, 33-67.

- Figueredo, J. W. de, Hawrswell-Curtis, J. W. \& Williams, A. N., 1968. Nitrogen narcosis and performance under water. Ergonomics 11, 157-164.

- \& Flemming, N. C., 1967. The efficiency of divers breathing oxy-helium. Ergonomics 10, 311-319.

Barnard, E., 1961. Visual problems underwater. Proc. R. Soc. Med. 54, 9-10.

Barnes, H., 1967. Ecology and experimental biology. Helgoländer wiss. Meeresunters. 15, 6-26. 
BARNETT, P. R. \& HARDY, B. L., 1967. A diver-operated quantitative bottom sampler for sand macrofauna. Helgoländer wiss. Meeresunters. 15, 390-398.

Bennetr, P. B., 1966. The aetiology of compressed air intoxication and inert gas narcosis. Pergamon Press, Oxford.

- Poulton, E. C., Carpenter, A. \& Catron, M. J., 1967. Efficiency at sorting cards in air and a 20 percent oxygen-helium mixture at depth down to $100 \mathrm{f}$. and in enriched air. Ergonomics 10, 53-62.

BERNARD, F., 1967. Réalisation d'une station automatique d'enregistrement des facteurs physicochimiques dans la zone des marées. Helgoländer wiss. Meeresunters. 15, 353-360.

Berthold, G., 1882. Ober die Verteilung der Algen im Golf von Neapel nebst einem Verzeichnis der bisher daselbst beobachteten Arten. Mitt. zool. Stn Neapel 3, 393-537.

Bowen, H., Anderson, B. \& Promisl, D., 1966. Studies of divers' performance during the Sealab II project. Hum. Factors 8, 183-199.

BRETT, C. E., 1964. A portable hydraulic diver operated dredge-sieve for sampling subtidal macrofauna. J. mar Res. 22, 205-209.

Chapman, C. J. \& Rice, A. L., 1971. Some direct observations on the ecology and behaviour of the Norway lobster Nepbrops norvegicus. Mar. Biol. 10, 321-329.

Choutrau, J. \& Corriol, J. H., 1971. Physiologische Aspekte des Tiefseetauchens. Endeavour 30,$110 ; 70-76$.

ChRISTIANsson, R. A., 1968. A study of visual acuity underwater using an automatic Landolt ring presentation technique. Ocean Systems Rep. 10, 8-128.

ClARK, T. A., 1970. Territorial behaviour and population dynamics of a pomacentrid fish, the Garibaldi, Hypsypops rubicauda. Ecol. Monogr, 40, 189-212.

Connelt, J. H., 1961. The influence of interspecific competition and other factors on the distribution of the barnacle Chthamalus stellatus. Ecology 42, 710-723.

- 1970. A predator-prey system in the marine intertidal region. I. Balanus glandula and several predator species of Thais. Ecol. Monogr. 40, 49-78.

Dohrn, A., 1880. Bericht über die Zoologische Station während der Jahre 1879 und 1880. Mitt. zool. Stn Neapel, 2, 495-514.

Dybern, B., 1969. Distribution and ecology of the tunicate Ascidiella scabra (Mürler) in the Skagerrak-Kattegat area. Ophelia 6, 183-201.

Fager, E. W., Flechsig, A. O., Ford, R. F., Chutter, R. I. \& Ghelardi, R. J., 1966. Equipment for use in ecological studies using Scuba. Limnol. Oceanogr. 11, 503-509.

Faust, K. J. \& BeckmanN, E. L., 1966. Evaluation of a swimmer's airmwater lens system. Milit. Med. 131, 779-788.

FORSTNER, H. \& RÜTzLER, K., 1969. Two temperature compensated current meters for use in marine ecology. J. mar. Res. 27, 263-271.

- - 1970. Measurements of the micro-climate in littoral marine habitats. Oceanogr. mar. Biol. 8, 225-249.

Fricke, H. W., 1966a. Zum Verhalten des Putzerfisches Labroides dimidiatus. Z. Tierpsychol. $23,1-3$.

- 1966b. Attrappenversuche mit einigen plakatfarbigen Korallenfischen im Roten Meer. Z. Tierpsychol. 23, 4-7.

- 1970. Ein mimetisches Kollektiv - Beobachtungen an Fischschwärmen, die Seeigeln nachahmen. Mar. Biol. 5, 307-314.

- 1971. Fische als Feinde tropischer Seeigel. Mar. Biol. 9, 328-338.

Frankenhauser, M., Graff-Lonnevig, V. \& Hesser, C. M., 1960. Psychomotor performance in man as effected by high oxygen pressure. Acta physiol. scand. 50, 1-7.

GISLÉN, T., 1929/30. Epibioses of the Gullmar Fjord. P. 1. Geomorphology and hydrography. 2. Matine sociology. (Kristinebergs Zoologiska Station, 1877-1927.) SkrSer. K. svenska VetenskAkad. 1929 (3), 1-123; 1930 (4), 1-380.

Goreau, T. F. \& Goreau, N. J., 1959. The physiology of skeleton formation in corals II. Calcium deposition by hermatypic corals under various conditions in the reef. Biol. Bull. mar. biol. Lab., Woods Hole 117, 239-250.

- - 1960. The physiology of Skeleton formation in corals, IV. On isotopic equilibrium 
exchange of calcium between corallum and environment in living and dead reefbuilding corals. Biol. Bull. mar, biol. Lab., Woods Hole 119, 416-427.

Gray, J. S. \& Ventilia, R. J., 1971, Pollution effects on micro- and meiofauna of sand. Mar. Pollut. Bull. 2, 39-43.

Greve, W., 1968. The "Planktonkreisel", a new device for culturing zooplankton. Mar. Biol. 1, $201-203$.

HAAGE, P. \& Jansson, B. O., 1970. Quantitative studies of the Baltic Fucus belt macrofauna I. Quantitative methods. Ophelia 8, 187-195.

Hamilton, R. W. Jr., Maclnnis, J. B., Noble, A. D. \& Schreiner, H. R., 1966. Saturation diving to 650 feet. Ocean Systems tech. Mem. 114.

HAUENSCHILD, C., 1970. Die Zucht von niederen marinen Wirbellosen und ihre Anwendung in der experimentellen Zoologie. Helgoländer wiss. Meeresunters. 20, 249-263.

Haux, G., 1969. Tauchtechnik. Springer, Berlin, 1, 1-269.

- 1970. Tauchtechnik. Springer, Berlin, 2, 1-288.

Hemmings, C. C., 1971. Fish Behaviour. In: Underwater science. Ed. by J. D. Woons \& J. N. Lythgoe. Oxford Univ. Press, London, 141-174.

Hull, S., 1967. Those remarkable little work boats. Geol. mar. Technol. 3, 22-40.

JATZKE, P., 1970. The "T'richterkreisel", an in situ device for cultivating marine animals in tidal currents. Helgoländer wiss. Meeresunters. 20, 685-690.

Jones, N. S. \& KatN, J. M., 1967. Subtidal algal colonisation following the removal of Echinus. Helgoländer wiss. Meeresunters. 15, 460-466.

KarN, J. M., 1971. Continuous recording of underwater light in relation to Laminaria distribution. In: Fourth European marine biology symposium. Ed by D. J. CrIsp, Cambridge Univ. Press, Cambridge, 335-346.

Kent, P. R. \& WeIsmanN, S., 1966. Visual resolution under water. U.S. nav, sub. mar. med. Center Rep. $\mathbf{4 7 6}$.

KrNNE, O., 1970a. Erste Erfahrungen mit dem Unterwasserlaboratorium „Helgoland“ (UWL-H). In: Systems 69 (Internationales Symposium über Zukunftsfragen). Deutsche Verl.Anst. Stuttgart, 293-301.

- 1970b. International symposium "Cultivation of marine organisms and its importance for marine biology". Opening address. Helgoländer wiss. Meeresunters. 20, 1-5.

Krtching, J., 1941. Studies in sublittoral ecology. 1. Submarine gully in Wembury Bay, South Devon. J. mar. biol. Ass. U. K. 19, 677-705.

Krasberg, A. R., 1967. The evolution of functional saturation diving. Underw. Ass. Rep. 2, $39-45$.

Kühlmann, D. H. \& Karst, H., 1967. Freiwasserbeobachtungen zum Verhalten von Tobiasfischschwärmen (Ammodytidae) in der westlichen Ostsee. Z. Tierpsychol. 24, $283-297$.

LABOREL, J., 1961. Le concrétionnement algal «corraligène» et son importance géomorphologique en Mediterranée. Recl. Trav. Stn. mar. Endoume 33, 117-173.

Larsson, B. A. S., 1968. SCuba-studies on vertical distribution of Swedish rodky-bottom echinoderms. A methodological study. Ophelia 5, 137-156.

Levinton, J. S., 1971. Control of Tellinacean (Mollusca: Bivalvia) feeding behaviour by predation. Limnol. Oceanogr. 16, 660-662.

LICKEY, M. E., EMIGH, R. L. \& RANDLE, F. R., 1970. A recirculating seawater aquarium system for inland laboratories. Mar. Biol. 7, 149-152.

Lrmbaugh, C., 1961. Cleaning symbiosis. Scient. Am. 205, 42-49.

- \& ReCHNITZRR, A. B., 1955. Visual detection of temperature-density discontinuities in water by diving. Science, N. Y. 121, 395.

LüNING, K., 1969. Growth of amputated and dark-exposed individuals of the brown alga Laminaria byperborea. Mar. Biol. 2, 218-223.

- 1971. Seasonal Growth of Laminaria byperborea under recorded underwater light conditions near Helgoland. In: Fourth European marine biology symposium. Ed by D. J. CRISP, Cambridge Univ. Press, Cambridge, 347-361.

Machan, R. \& OTT, J., 1972. Problems and methods of continuous in situ measurements of redox potentials in marine sediments. Limnol. Oceanogr. 17, 622-626. 
MoIntyre, A. D., Munro, A. L. \& Steele, J. H., 1970. Energy flow in a sand ecosystem. In: Marine food chains. Ed. by J. H. Steele. Univ. California Press, Berkely, 19-31.

Mues, S., 1962. Underwater medicine. Staples Press, London.

MILNE-EDWARDS, H., 1845. Recherches zoologiques faites pendant un voyage sur les côtes de la Sicile. 1. Rapport. Annls. Sci. nat. (Zool., Sér. 3) 1, 129-182.

Myrberg, A. A., Banner, A. \& Richard, J. D., 1969. Shark attraction using a video acustic system. Mar. Biol. 2, 264-276.

Neshyba, S, 1967. Pulsed light stimulation of marine biolumiscence in situ. Limnol. Oceanogr. $12,222-235$.

Neumann, A. C., 1966. Observations on coastal erosion in Bermuda and measurements of the boring rate of the sponge Cliona lampa. Limnol. Oceanogr. 11, 92-108.

Neushul, M. \& Haxo, F. T., 1963. Studies on the giant kelp Macrocystis. 1. Growth of young plants. Am. J. Bot. 50, 349-359.

NORTH, W. J., 1961. Experimental transplantation of the giant kelp, Macrocystis pyrifera. Int. Seaweed Symp. 4, 248-255.

Opum, H. T., 1971. Environment, power and society. Wiley-Interscience, New York, 331 pp.

- \& Ooum, E., 1955. Trophic structure and productivity of a windward coral reef commum nity on Eniwetok. Atoll. Ecol. Monogr. 25, 291-320.

Oтт, J., 1969. Mikroökologie von Phytalbeständen am Beispiel der Nematoden. Diss. Wien, $123 \mathrm{pp}$.

PAINE, R. T., 1966. Food web complexity and species diversity Am. Nat. 100, 65-75.

- \& VADAs, R. L., 1969. The effects of grazing by sea urchins Strongylocentrotus ssp., on benthic algal populations. Limnol. Oceanogr. 14, 710-719.

Pamatmat, M. \& Fenton, D., 1968. An instrument for measuring subtidal benthic metabolism in situ. Limnol. Oceanogr. 13,537-540.

PAtTon, W. K., 1967. Studies on Domecia acantopbora, a commensal crab from Puerto Rico, with particular reference to modifications of the coral host and feeding habits. Biol. Bull. mar. biol. Lab., Woods Hole 132, $56-67$.

Piccard, J., 1966. The future of deep sea exploration. Oceanology int. 1, 50-53.

Poulton, E. C., Catton, M. J. \& Carpenter, A., 1964. Efficiency at sorting cards in compressed air. Brit. J. ind. Med. 21, 242-245.

REBrKofF, D., 1967. The case for unmanned underwater systems. Sea Front. 13, 130-136.

RechntTzer, A., 1967. Deep submersibles. Oceanology int. 2, 24-25.

Rroads, D. C. \& Young, D. K., 1971. Animal-sediment relations in Cape Cod Bay, Massachusetts. II. Reworking by Molpadia oolitica (Holothuroidea). Mar. Biol. 11, 255-261.

Rice, A. I. \& Chapman, C. J., 1971. Observations on the burrows and burrowing behaviour of two mud dwelling decapod crustaceans, Nephrops norvegicus and Gonoplax rbomboides. Mar. Biol. 10, 330-342.

Ried, R., 1963. Probleme und Methoden der Erforschung des litoralen Benthos. Zool. Anz. (Suppl.) 26, 505-567.

- 1967. Die Tauchmethode, ihre Aufgaben und Leistungen bei der Erforschung des Litorals; eine kritische Untersuchung. Helgoländer wiss. Meeresunters. 15, 294-351.

- \& MACHAN, R., 1972. Hydrodynamic patterns in lotic intertidal sands and their bioclimatological implications. Mar. Biol. 13, 179-209.

Russel, C., 1967. The ecology of some free living Ectocarpaceae. Helgoländer wiss. Meeresunters. 15, 155-162.

Smith, K., Burns, K. A. \& Trat, J. M., 1972. In situ respiration of benthic communities in Castle Harbour, Bermuda. Mar. Biol. 12, 196-199.

Stensö̈k, O., 1942. Das Verhalten von Planaria alpina Dana in der Natur und im Laboratoriumsversuch. Memorie Ist. ital. Idrobiol. 1, 63-75.

Stephens, J. S. Jr., Jornson, R. K., Key, G. S. \& McCosteer, J. E., 1970. The comparative ecology of three sympatric species of California blennies of the genus Hypsoblenniws GiLL (Teleostomi, Bleniidae). Ecol. Monogr. 40, 213-233.

SvobodA, A., 1970. Simulation of oscillating water movement in the laboratory for cultivation of shallow water sedentary organisms. Helgoländer wiss. Meeresunters. 20, 676-684. 
- Okologie und Systematik der Gattung Aglaophenia (Hydroida, Thecaphora) in der Adria. (In prep.)

Svoвоda, B. \& Svовоda, A. Verhalten und Okologie von Garnelen der Gattung Periclimenes auf Aktinien in der Adria. (In prep.)

Teal, J. M., 1962. Energy flow in the salt marsh ecosystem of Georgia. Ecology 43, 614-624.

Tolbert, W. H., Payne, R. H. \& Salzman G. G., 1964. An underwater crane. Limnol. Oceanogr. 9, 150-151.

Velrmirov, B., 1973. Orientation of the sea fan Eunicella cavolinii related to water movement. Helgoländer wiss. Meeresunters. 24, 163-173.

WALKER, B., 1967. A diver-operated pneumatic core sampler. Limnol. Oceanogr. 12, 144-146.

Waterman, T. \& Forward, R., 1972. Field demonstration of polarotaxis in the fish Zenarchopterus. J. exp. Zool. 180, 33-54.

Watchell, P. L., 1967. Concepts of broad and narrow attention. Psychol. Bull. 68, 417-429.

Wettman, G., Egstrom, G. H. \& Christianson, R. H., 1967. Perceptual narrowing in divers: a preliminary study. Hum. Factors 8.

Woods, J. D., 1971. Microoceanography. In: Underwater science. Ed. by: J. D. Woods \& J. N. Lythgoe, Oxford Univ. Press, London, 291-317.

- \& Lythgoe, J. N. (Eds), 1971. Underwater science. Oxford Univ. Press, London, 330 pp.

Young, D. K. \& Rroads, D. C., 1971. Animal-sediment relations in Cape Cod Bay, Massachuetts. I. A transsect study. Mar. Biol. 11, 242-254.

Youngrluth, M. J., 1968. Aspects of the ecology and ethology of the cleaning fish, Labroides phtbiropbagus Randall. Z. Tierpsychol. 25, 915-932.

ZnLroux, E. J., 1969. A continuous recirculating culture system for planktonic copepods. Mar. Biol. 4, 215-218.

- \& LACKre, N. F., 1970. Advances in the continuous culture of planktonic copepods. Helgoländer wiss. Meeresunters. 20, 325-332.

Author's address: Dr. J. A. OTt

I. Zoologisches Institut

Universität Wien

Wien I

Dr.-Karl-Lueger-Ring 1

Austria 